\title{
FROM TESTABLE HYPOTHESES TO ETHICAL PAPERS AND IMPROVED HEALTH SERVICES
}

Received: Sept 15, 2019

Accepted: Sept 30, 2019

Marlen Yessirkepov ${ }^{\mathbf{1}^{*}}$ https://orcid.org/0000-0003-2511-6918

Armen Yuri Gasparyan ${ }^{2}$ https://orcid.org/0000-0001-8749-6018

1Department of Biology and Biochemistry, South Kazakhstan Medical Academy, Shymkent, Kazakhstan

2Departments of Rheumatology and Research and Development, Dudley Group NHS

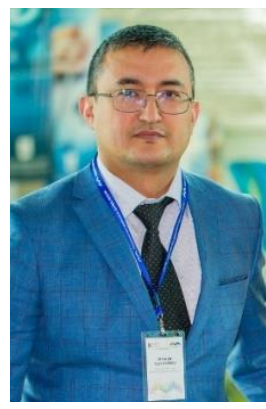

Foundation Trust (Teaching Trust of the University of Birmingham, UK), Russells Hall Hospital, Dudley, West Midlands, UK

\section{*Corresponding author:}

Marlen Yessirkepov, MD, PhD, Professor, Department of Biology and Biochemistry, South Kazakhstan Medical Academy, Al-Farabi Square 1/1, Shymkent, 160019, Kazakhstan;

Twitter handle: @MYessirkepov; E-mail: marlen-forex@inbox.ru

Keywords: Central Asia, Periodicals as topic, Hypothesis, Research design

How to cite: Yessirkepov M., Gasparyan AY. From testable hypothesis to ethical papers and improved health services. Cent Asian J Med Hypotheses Ethics 2020;1(1):10-13. https://doi.org/10.47316/cajmhe.2020.1.1.01

Publishing an informative, useful, and attractive journal has been a difficult task throughout the history of scientific communications. Print publishing has had its own hardships that kept editors and publishers busy with time-consuming technological processes, requiring specific skills and abundant financial investments. With the advent of digital media and Open Access, scholarly activities and knowledge transfer have accelerated and facilitated globally affordable online publishing practices.
From a technical viewpoint, launching and maintaining an online periodical is much easier now than, let say, a decade ago. There are now various online tools and platforms that help evaluating and editing manuscripts within a short time. The same platforms, integrated with digital libraries and social media channels, allow reliable archiving and postpublication communications. By integrating with numerous social media sites, the journal contents are now promoted and evaluated based on their reader views, downloads, and comments. Not only scholarly articles, but also properly archived 


\section{Central Asian Journal of Medical Hypotheses and Ethics|}

2020; Vol 1 (1)

reviewer and reader comments are currently counted as publication units and tracked by crediting platforms such as Publons (https://publons.com).

The adherence to a set of publication standards and evaluation criteria from the first issue should be prioritized for a new journal. Each submission should be analyzed in view of the published literature to avoid redundancies, poorly justified hypotheses, and misleading statements. To meet high standards, the journal editors, reviewers, and authors should familiarize themselves with updated recommendations of the global editorial associations, such as the International Committee of Medical Journal Editors (ICMJE), the Committee on Publication Ethics (COPE) and the Council of Science Editors (CSE) [1]. Drafting and regularly revising the journal instructions in accordance with the updated editorial guidance should become a strategy for attracting ethical and useful submissions. The journal evaluation criteria are set by bibliographic databases, such as Scopus and MEDLINE. The editors who wish to advance their publishing standards and increase the scientific prestige of their start-up journals can apply and, at least, attempt to meet the evaluation criteria of the bibliographic databases.

Most prestigious bibliographic databases are currently raising their bars for covering truly reliable, ethical, and useful contents. To satisfy the journal evaluation criteria, the editors are obliged to clearly formulate their aims and scope of coverage. Although a wide scope is advantageous for attracting numerous submissions in different subject categories, narrowing priorities to the needs of the audience and professional capacities of the editorial board can increase the evaluation quality.

Actively seeking great articles of experienced authors and supporting novice authors in their attempts to present new ideas are also optimal editorial strategies for a new journal. To implement such strategies, the journal needs a responsible editorial team, acting in line with the publication ethics norms and generously sharing their experience at the peer review.

With the expanding network of research and academic collaborations, publishing periodicals for international professional communities is becoming a global trend. Even journals primarily serving interests of and published by their local institutions may internationalize by widening geography of their editorial teams and welcoming articles of regional or global interest. The most important task, however, relates to inviting board members primarily representing the country where the journal is published and ensuring all those members are experts in the scientific fields covered by the journal [2].

Undoubtedly, launching a journal in a region with low publication activity and poor visibility of scholarly works is a daunting task. Central Asia is one such region. To track the regional research studies, the Medical Subject Headings (MeSH) of the National Library of Medicine (NLM) of U.S. introduced "Central Asia" as a keyword of geographical area comprising Kazakhstan, Kyrgyzstan, Tajikistan, Turkmenistan, and Uzbekistan (https://bit.ly/2m0UB0G). Most academic problems in the region stem from the Soviet-style rigid research management, lack of access to English sources, and inappropriate crediting of creative scholarly activities. In these countries, publication activity is uneven, absolute number of indexed articles is low, and targets are predominantly nonmainstream journals without indicators from prestigious citation databases [3]. The lack of the Central Asian authors' English proficiency and absence of local journals indexed by evidence-based databases are among the main factors negatively affecting the scientific prestige in the region [3]. Although the number of indexed articles is steadily increasing in Kazakhstan, along with improving access to databases and other essential sources of scientific information, there are 
still issues with choosing quality target journals and collaborating with English-speaking experts [4].

In the current scenario selecting local contributors to a Central Asian journal is apparently problematic. It is partly because of the poor visibility or nonexistence of rigorous peer review in the absolute majority of local journals. Subsequently, the culture of crediting reviewers as the gatekeepers of quality journals is not established in the region. A quick look at Publons reviewer activity in Central Asian countries suggests that the most active contributors represent Kazakhstan, particularly Nazarbayev University (https://bit.ly/2oapzUK). The visibility of reviewer activity in other countries is too low or nonexistent (Tajikistan and Turkmenistan). It is unclear how local journals manage the peer review and evaluate the integrity of the submissions.

Admittedly, the practice of evaluating ethics statements and testing for redundancies in the submissions to local journals is poorly established. No any currently published local or regional periodical has a designated editorial post for evaluating research and publication ethics, let alone working hypotheses, statistics, and study designs. The current situation is confounded by limited opportunities for graduate and postgraduate education in bioethics [5], no transparency of Institutional Review Boards (IRB) proceedings [6], and underdeveloped research culture [7].

The question arises as to whether it is possible to solve these issues with research culture and increase volume of ethical and truly influential works in Central Asia. The answer lies within the question. Definitely, it is possible to achieve great results by campaigning for ethical research and quality output. A new journal bringing about improvements in evaluating research works and distributing innovative ideas may improve the situation. Globally, there is a huge gap between an unprecedented increase of research works and poor evaluation of background concepts or hypotheses, resulting in the multiplication of useless publications [8]. By attempting to publish more, numerous journals fail to scrutinize the peer review and selection of research reports and reviews with properly formulated working hypotheses, aims, and designs. At the same time, not many established journals publish scientific hypotheses as a separate article type, thus creating a window of opportunity for emerging ethical sources.

By introducing this inaugural issue of the Central Asian Journal of Medical Hypotheses and Ethics (CAJMHE), the editors attempt to fill the gaps in the regional publishing enterprise. The Journal follows the principles of transparency and best practice in open access publishing [9]. The global initiative of Open Access is still in the process of implementation across Central Asian countries. The Journal takes advantage of publishing open-access articles and tries to increase visibility of local authors. The published articles are for distribution in line with the statements publicized by the Open Access Scholarly Publishers Association (OASPA) [9]. To reach wider audience, the editors employ social media channels, which are increasingly recognized as useful tools for scholars entering the world of open science [10].

The Journal authors are welcome to submit hypotheses as part of their original research and overviews and discuss with the editors designs of their future research studies and related ethical issues. Regional experts with interest in research methodology, medical hypotheses, and research and publication ethics are invited to join the Journal's promising initiative. The CAJMHE is now supported by numerous international editorial board members with vast research, writing, and reviewing experience. Equipped with updated editorial policies and following all ethical norms, it is hoped that the CAJMHE will soon become a reliable platform for seasoned and novice authors who wish to share their innovative ideas, establish research culture, and advance healthcare in Central Asia. 


\section{REFERENCES}

1. Gasparyan AY. Familiarizing with science editors' associations. Croat Med J 2011;52(6):735-739.

2. American Medical Writers Association; European Medical Writers Association; International Society for Medical Publication Professionals. AMWA-EMWA-ISMPP joint position statement on predatory publishing. Curr Med Res Opin 2019: [Epub ahead of print].

3. Yamshchikov GV, Schmid GP. Publication practices and attitudes towards evidence-based medicine in central Asia. Lancet Glob Health 2013;1(2):e73-e74.

4. Yessirkepov M, Nurmashev B, Anartayeva M. A Scopus-Based Analysis of Publication Activity in Kazakhstan from 2010 to 2015: Positive Trends, Concerns, and Possible Solutions. J Korean Med Sci 2015;30(12):1915-1919.

5. Chaschin M, Mishatkina T, Guryleva M, et al. Developing National Systems for Research Ethics Education in Eastern Europe and Central Asia. Pharm Med 2008;22(5):289-295.

6. Kundiiev YI, Vitte PN, Chashchin N, et al. Developing National Systems for Ethical Review in Eastern Europe and Central Asia: Legitimacy and Responsibility. Pharm Med 2008;22(5):285-287.

7. Jonbekova D. Educational research in Central Asia: methodological and ethical dilemmas in Kazakhstan, Kyrgyzstan and Tajikistan. Compare 2018; [Epub ahead of print].

8. Jokstad A. Launching a new journal on the Internet in an era of fake science news and predatory publishingdoing the right thing and doing the thing right. Clin Exp Dent Res 2017;3(1):3-4.

9. Principles of Transparency and Best Practice in Scholarly Publishing. Available from: https://oaspa.org/principles-of-transparency-and-best-practice-in-scholarly-publishing-3/ [Accessed September 15, 2019].

10. Mašić I, Begić E, Donev DM, et al. Sarajevo Declaration on Integrity and Visibility of Scholarly Publications. Croat Med J 2016;57(6):527-529.

\section{Ғылыми гипотезалардан этикалық мақалаларға және медициналық қызметтердің жақсаруына дейін}

Түйін сөздер: Орталық Азия, Тақырып ретінде мерзімді басылымдар, Гипотеза, Зерттеу дизайны

Дәйексөз үшін: Есиркепов М., Гаспарян А. Ю. Сыналатын гипотезалардан этикалық құжаттарға және медициналық қызметтердің жақсаруына дейін. Медициналық гипотеза мен этиканың Орта Азиялық журналы. - 2020 - №1 (1). - Б. 10-13. https://doi.org/10.47316/cajmhe.2020.1.1.01

От научных гипотез к этичным статьям и улучшению медицинского обслуживания Ключевые слова: Центральная Азия, Периодика как тема, Гипотеза, Дизайн исследования Для цитирования: Есиркепов М., Гаспарян А. Ю. От научных гипотез к этичным статьям и улучшению медицинского обслуживания. Центральноазиатский журнал медицинских гипотез и этики. - 2020. - №1(1). - C. 10-13. https://doi.org/10.47316/cajmhe.2020.1.1.01 